\title{
OPTIMIZATION OF BIODIESEL FROM ARGEMONE OIL WITH DIFFERENT REACTION PARAMETERS AND PERFORMANCE ANALYSIS IN CI ENGINE
}

\author{
Parmjit Singh $^{1}$, Sandeep Kumar Duran ${ }^{2}$, Amanpreet Singh ${ }^{3}$ \\ ${ }^{I}$ M-Tech scholar, Mechanical Engineering Department, LPU, Punjab, India \\ ${ }^{2}$ Assistant professor, Mechanical Engineering Department, LPU, Punjab, India \\ ${ }^{3} M$-Tech scholar, Mechanical Engineering Department, LPU, Punjab, India
}

\begin{abstract}
This experiment work is to investigate the performance parameters of single cylinder, four stroke engine connected to eddy current dynamometer fuelled with argemone biodiesel and blend with diesel fuel under different load condition $(0 \%, 20 \%, 40 \%$, $60 \%, 80 \%, 100 \%)$ and constant engine running speed. The performance parameters consist of brake power (BP), brake thermal efficiency (BTHE), and brake specific fuel consumption (BSFC). The argemone mexicana oil was used for production of biodiesel. The transesterification process was used for production of argemone oil methyl ester by using methanol in the presence of sodium metal as a catalyst. The process undergoing various reaction conditions with molar ratio (1:6, 1:3, 1:9 oil to methanol), reaction time $(60 \mathrm{~min}, 90 \mathrm{~min}, 120 \mathrm{~min})$, reaction temperature $\left(55^{\circ} \mathrm{C}, 65^{\circ} \mathrm{C}, 75^{\circ} \mathrm{C}, 85^{\circ} \mathrm{C}\right)$ and catalyst $(1 \%, 1.5 \%, 2 \%, 2.5 \% \mathrm{w} / \mathrm{w} \mathrm{of} \mathrm{oil})$ effects the fuel properties of argemone biodiesel. The most favorable conditions for transesterification of argemone oil with methanol in the presence of sodium metal as a catalyst was found with molar ratio 1:6 (oil to methanol), reaction time 120 min, reaction temperature $75^{\circ} \mathrm{C}$ and catalyst $1.5 \%$ (w/w of oil). The fuel properties were calculated and compared with Diesel. The result shows that argemone biodiesel blend (AB10 and AB20) have improved fuel property and brake thermal efficiency, brake power and specific fuel consumption value closer to diesel value.
\end{abstract}

Keywords: Argemone mexicana oil, Transesterification, Sodium metal Catalyst, Methyl ester, Biodiesel Properties, Engine Performance.

\section{INTRODUCTION}

The worldwide has increased demand of energy supply of fossil fuel source such as petroleum, coal and natural gas. Highly dependency on fossil fuel leads to increase the cost of petroleum, environmental degradation and their import bill [1]. Hence long period energy security is required to develop a new alternative fuel. Biodiesel is a biodegradable, eco-friendly, non-toxic, clean burning and an alternative fuel for diesel engine [2]. It is derived from the different types of vegetables oil (edible and non-edible oil) and animal fats. Different methodologies to produce Biodiesel are [3]:

i. Direct use/blending

ii. Heating

iii. Micro-emulsion

iv. Pyrolysis

v. Transesterification

In the direct method straight vegetable oil is used in the diesel engine without any engine modification. The main advantage of this method is complete accessibility and renewability. The straight vegetable oil arises few problems in engine like injector coking, ring sticking, poor atomization and improper combustion due to high viscosity and density of vegetable oil.
Heating is the process in which the viscosity of the vegetable oil varies with the temperature, affecting the efficiency of the engine.

Pyrolysis is the process of conversion of one substance into another substance using heat. Catalyst is used to increase the rate of reaction. Lower hydrocarbons are obtained as the product of pyrolysis of vegetable oil that can be used as a fuel.

In Micro emulsion, colloidal dispersion of fluid microstructures $(1-150 \mu \mathrm{m})$ in solvent forming two immiscible phases take place.

Transesterification is a chemical reaction in which the vegetable oil, a triglyceride react with alcohol (methanol or ethanol) in the presence of catalyst (homogenous and heterogeneous), producing a mixture of fatty acid (methyl or ethyl ester) and glycerol. Different parameters considered during the transesterification reaction are:

$\begin{aligned} \text { i. } & \text { Molar ratio (vegetable oil to alcohol ) } \\ \text { ii. } & \text { Reaction time } \\ \text { iii. } & \text { Reaction temperature } \\ \text { iv. } & \text { Stirring speed } \\ \text { v. } & \text { Catalyst (homogenous and heterogeneous) } \\ \text { vi. } & \text { Catalyst concentration (\% w/w of oil) }\end{aligned}$


Argemone mexicana is used as non-edible oil resource for the production of biodiesel. Argemone mexicana belongs to papveraceae (poppy) family and the entire species belong to the mexicana prickly poppy. It is commonly known as Shialkanta and Satyanashi in India. In India it is found on the road side, waste land and field. This plant have yellow flower, branching herb with yellow juice and height varies between 0.3 to 0.12 meters. The plant is self-productive [5]. The argemone oil consists of linoleic acid (54-61\%), oleic acid (21-33\%) and toxicity attributes mainly two alkaloids, sanguinarine and dihydro-sanguinarine [6]. The aim of this work is to find optimum conditions and properties of argemone oil methyl ester. The properties are compared with Diesel Fuel and show that argemone biodiesel meet the properties of diesel standard fuel.

Table -1: Fatty acid composition of argemone oil [9]

\begin{tabular}{|l|l|}
\hline $\begin{array}{l}\text { Property } \\
\text { Fatty acid composition (\%) }\end{array}$ & Argemone oil \\
\hline Oleic acid (C 18:1) & 40.0 \\
\hline Linoleic acid (C 18:2) & 36.6 \\
\hline Palmitic acid (C 16:0) & 14.7 \\
\hline Stearic acid(C 18:0) & 6.75 \\
\hline Palmitoleic acid(C 16:1) & 1.3 \\
\hline Linolenic acid (C 18:3) & 0.3 \\
\hline Arachidic acid (C 20:0) & 0.3 \\
\hline Behenic acid (C 22:0) & 0.2 \\
\hline Myristic acid (C 14:0) & 0.1 \\
\hline
\end{tabular}

\section{MATERIALS AND METHOD}

The argemone mexicana seeds were purchased from local market in hoshiarpur. Argemone oil was extracted using Solvent Extraction Method with petroleum esters and hexane as a solvent. The value of free fatty acid of argemone oil was less than $2 \%$ hence single step transesterification method was used for production of biodiesel. In this method, transesterification of non-edible oils, triglyceride reacts with three molecule of methanol in the presence of homogenous as catalyst, producing a mixture of three parts of fatty acid methyl ester and one part of glycerol. The triglyceride was converted into mono-alkali ester and glycerol. The alcohol (methanol and ethanol) and catalyst (sodium hydroxide, potassium hydroxide and sodium metal) were provided in the laboratory. The entire experiments were performed in SSS NIRE (Sardar Swarn Singh National Institute of Renewable Energy) Kapurthala, Punjab.

Formula:

$$
\text { Acid Value }=\frac{\text { Volume of KOH used } \times 0.1 \times 56.1}{\text { Weight of Sample }}
$$$$
\text { Free Fatty Acid Value }=\frac{\text { Acid Value }}{2}
$$

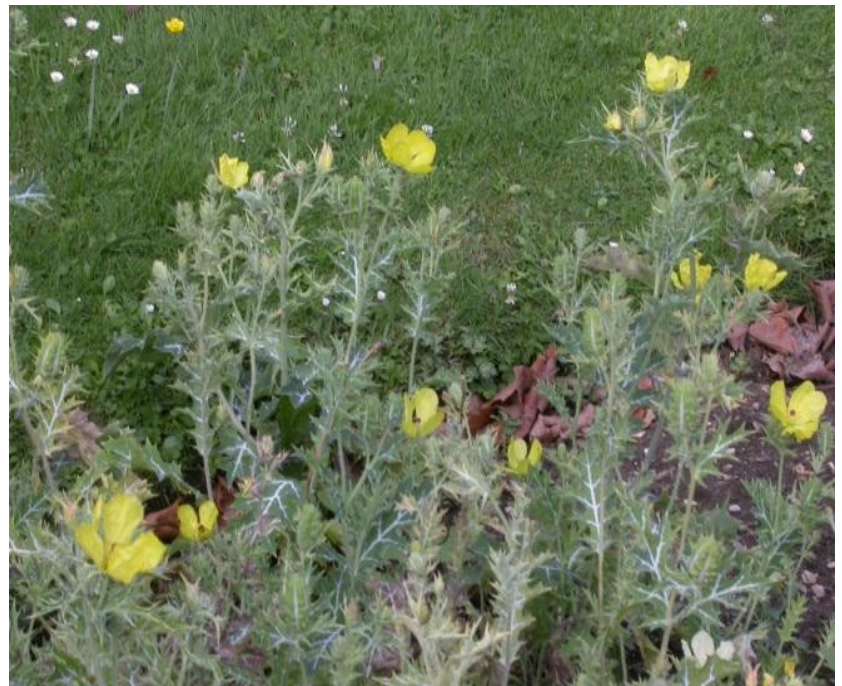

Fig -1: Argemone Mexicana Plant.

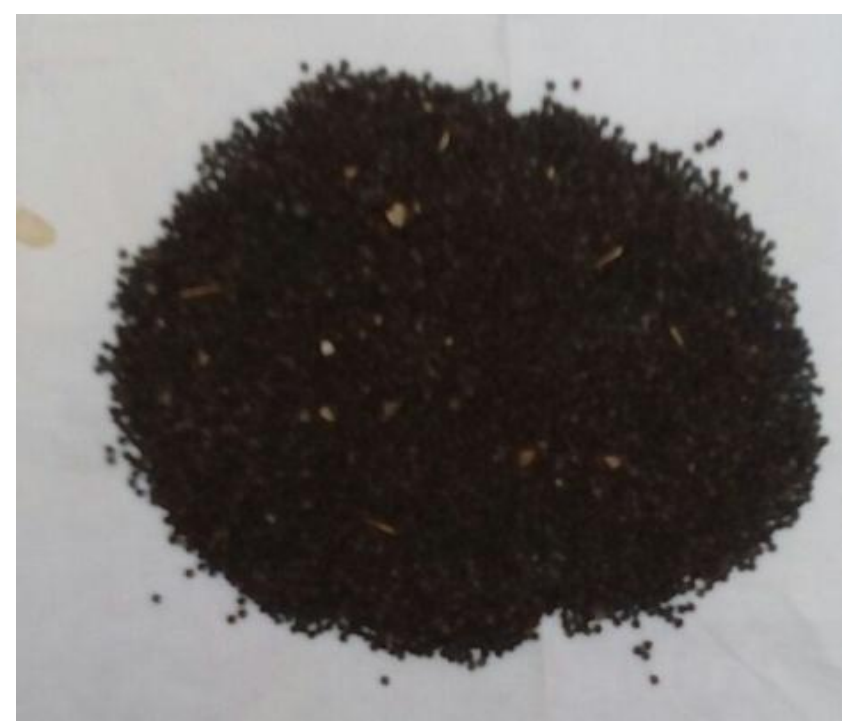

Fig -2: Argemone mexicana seeds.

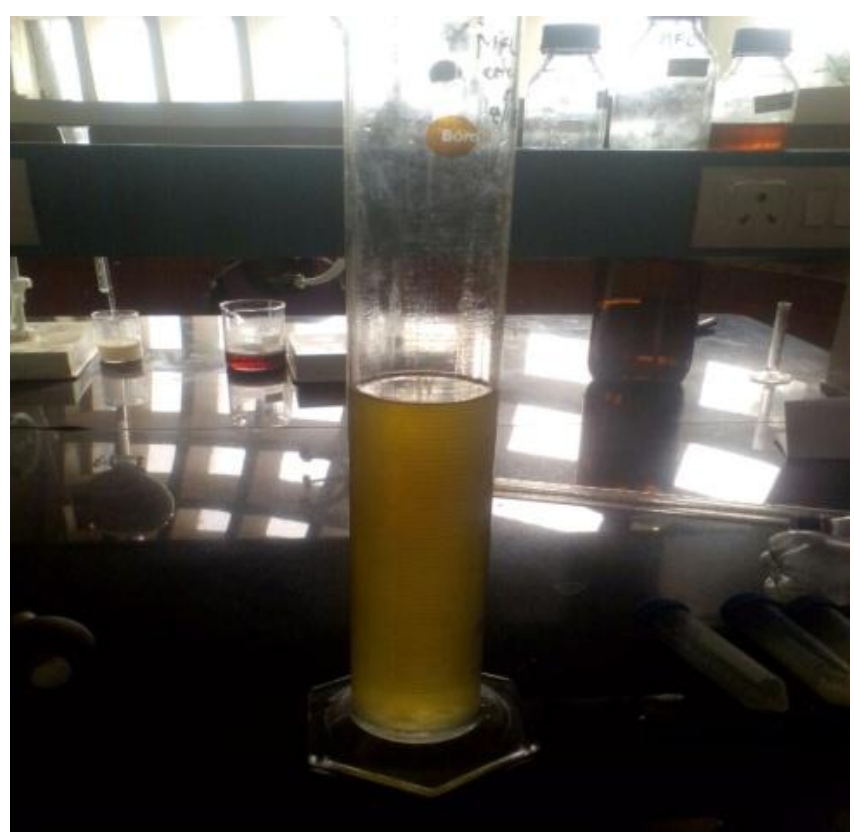

Fig -3: Argemone mexicana oil. 


\subsection{Production of Biodiesel for Argemone oil}

Feedstock : Argemone mexicana oil

Instrument : Redley reactor

Base catalyst : $\mathrm{NaOH}, \mathrm{KOH}, \mathrm{NA}$ metal of $1 \%$,

$1.5 \%, 2 \%, 2.5 \% \mathrm{w} / \mathrm{w}$ of oil

Reactant $: 1: 6,1: 3,1: 9$ (oil to methanol)

\subsection{Biodiesel Setup}

The reaction was carried out in Biodiesel Redley Reactor equipped with reflux condenser, magnetic stirrer and thermometer. It consists of water jackets, external heater and condenser. The suitable mixing and turbulence for accelerating the reaction was done by supplementary impeller, attached mechanically to spindle.

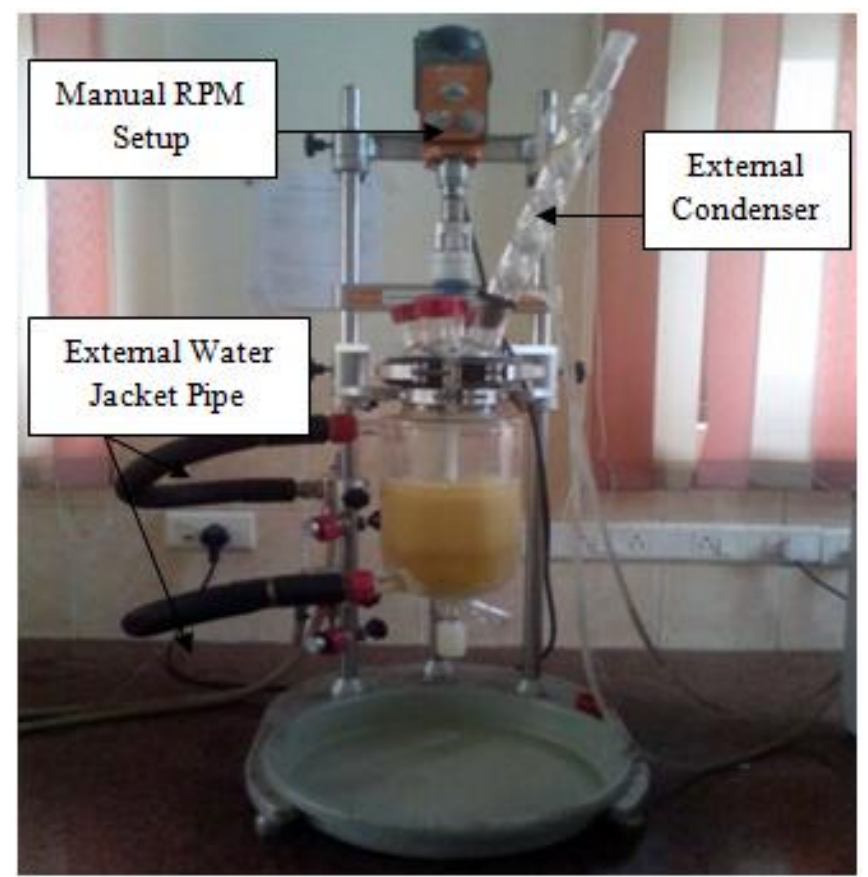

Fig -4: Biodiesel Setup

\subsection{Transesterification Process}

During experiment, $1000 \mathrm{ml}$ of argemone oil was taken in the biodiesel preparation unit and preheated at $75^{\circ} \mathrm{C}$ for number of experiment. Preheating was used to eliminate unnecessary moisture content from the oil. According to molar ratio 1:3, 1:6, 1:9, 1:12 (oil to methanol ratio), take $151 \mathrm{ml}, 302 \mathrm{ml}, 454 \mathrm{ml} 605 \mathrm{ml}$ of methanol and catalyst concentration 1\%, 1.5\%, 2\%, 2.5 (9.1 gm, $13.65 \mathrm{gm}, 18.29$ $\mathrm{gm}$ and $22.75 \mathrm{gm} \mathrm{w} / \mathrm{w}$ of oil) of sodium hydroxide, potassium hydroxide, and sodium metal in the three different beaker and stir until the catalyst gets fully dissolved. The sodium hydroxide, potassium hydroxide and sodium methoxide solution were poured into the hot argemone oil. The reaction temperature was maintained at varies $55^{\circ} \mathrm{C}, 65^{\circ} \mathrm{C}, 75^{\circ} \mathrm{C}, 85^{\circ} \mathrm{C}$ steady conditions and stirring speed was manually set to constant $650 \mathrm{rpm}$. Water bath (external heater) and reflux condenser were switched on after proper closing of the flask. The purpose of external heater unit was to maintain constant temperature of reaction and of condenser is to reflux back the vaporized methanol particles into the reactor. The whole mixture was continuous stirred at $650 \mathrm{rpm}$ for two hours. The mixture takes 24 hours to settle down. After 24 hours, two layers are formed. Top layer was biodiesel and bottom layer consist of glycerol and soap. The bottom layer was taken out and the top layer was washed for 10-15 times with hot water. Even after washing process small amount of alcohol and water contents were present in the biodiesel. These contents were removed using oven kept at $110^{\circ} \mathrm{C}$, thus obtaining pure biodiesel.

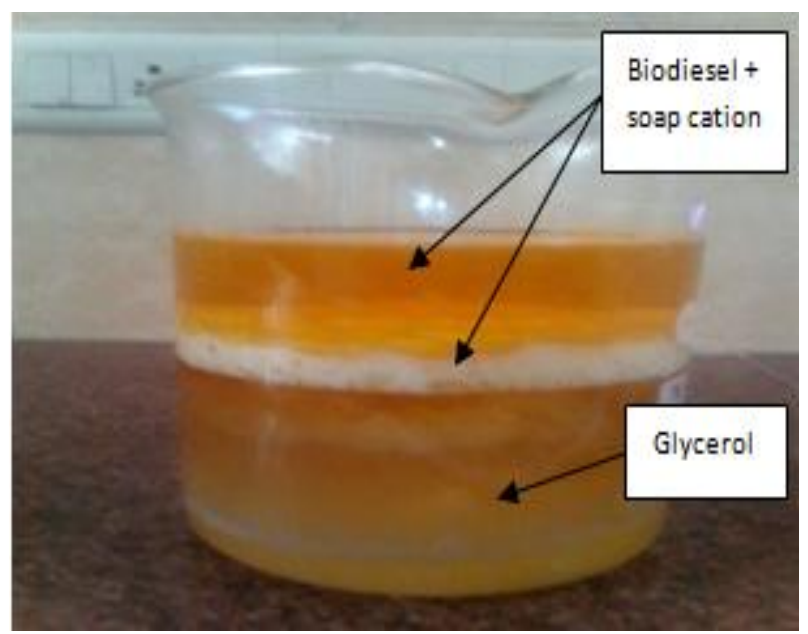

Fig -5: Biodiesel and Glycerol.

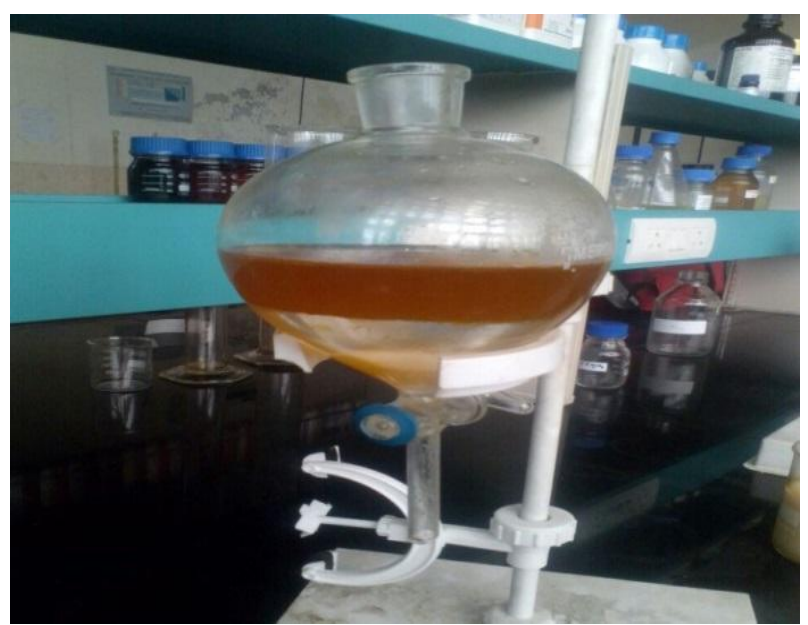

Fig -6: Soap and Glycerol Sepration by washing.

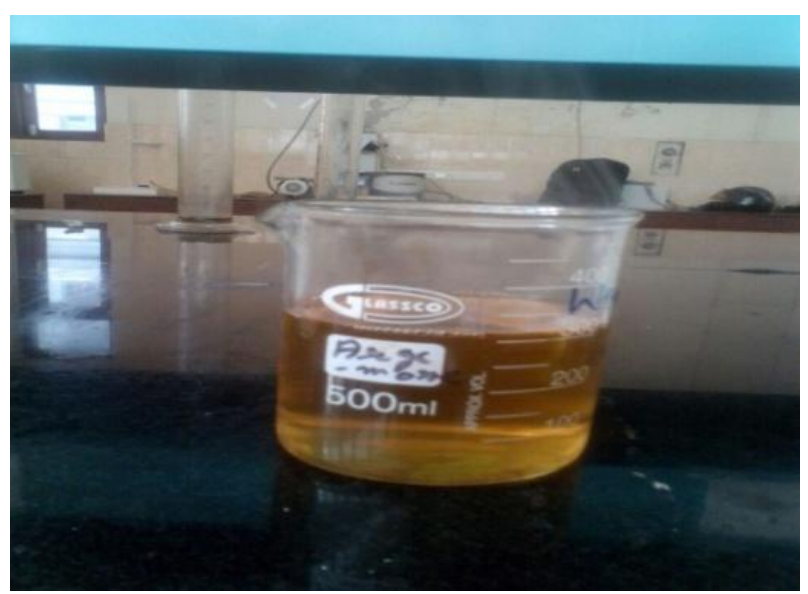

Fig -7: Pure Biodiesel. 


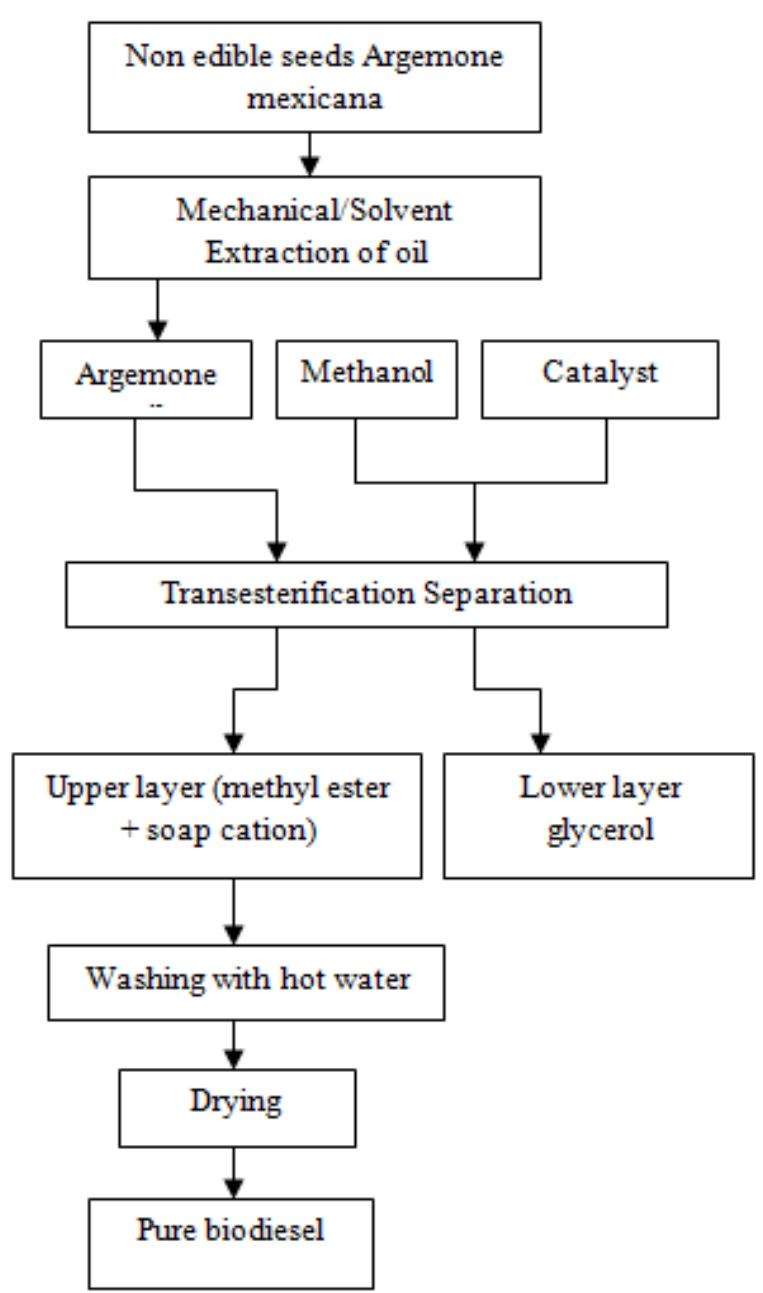

Fig -8: Process for Production of Biodiesel from Argemone oil.

\section{PERFORMANCE PARAMETERS ANALYSIS OF CI ENGINE}

\subsection{Expermental Fuel}

In this research investigation five blends were prepared $10 \%$ (v/v) argemone biodiesel with $90 \%$ (v/v) diesel fuel denoted by AB10 (argemone biodiesel blend). The experiment were conducted using diesel and argemone blend with diesel AB10, AB20, AB30.

\subsection{Expermental Setup and Procedure}

The experiment setup consist of single cylinder, four stroke, water cooled diesel engine connected to eddy current type dynamometer. The engine specification are shown in table 2. The crank angle sensor, load cell are fitted on the dynamometer and piezosensor fitted on the engine. The engine running speed is constant at 1500rpm. The "EnginesoftLV" software was used performance analysis for engine. The experiment were conducted using diesel and argemone blend with diesel AB10, AB20, AB30 under different load conditions $(0 \%, 20 \%, 40 \%, 60 \%, 80 \%, 100 \%)$ at constant speed $1500 \mathrm{rpm}$. The experimental setup is shown in figure 9.
Table -2: Engine Specification.

\begin{tabular}{|l|l|}
\hline Engine & $\begin{array}{l}\text { Kirloskar engine setup 1 cylinder, 4 } \\
\text { stroke }\end{array}$ \\
\hline Power rating & $3.5 \mathrm{KW}$ \\
\hline engine speed & $1500 \mathrm{RPM}$ \\
\hline Cylinder bore & $87.50 \mathrm{~mm}$ \\
\hline Stroke length & $110.00 \mathrm{~mm}$ \\
\hline Swept volume & $661.45 \mathrm{cc}$ \\
\hline Cooled type & Water cooled \\
\hline Compression ratio & 17.5 \\
\hline dynamometer & $\begin{array}{l}\text { Type eddy current , water cooled, } \\
\text { with loading unit }\end{array}$ \\
\hline Load indicator & Digital, supply 230 AC \\
\hline Rotameter & $\begin{array}{l}\text { Engine cooling } \\
\text { Calorimeter 25-250 LPH }\end{array}$ \\
\hline software & $\begin{array}{l}\text { "EnginesoftLV" Engine performance } \\
\text { analysis software }\end{array}$ \\
\hline
\end{tabular}

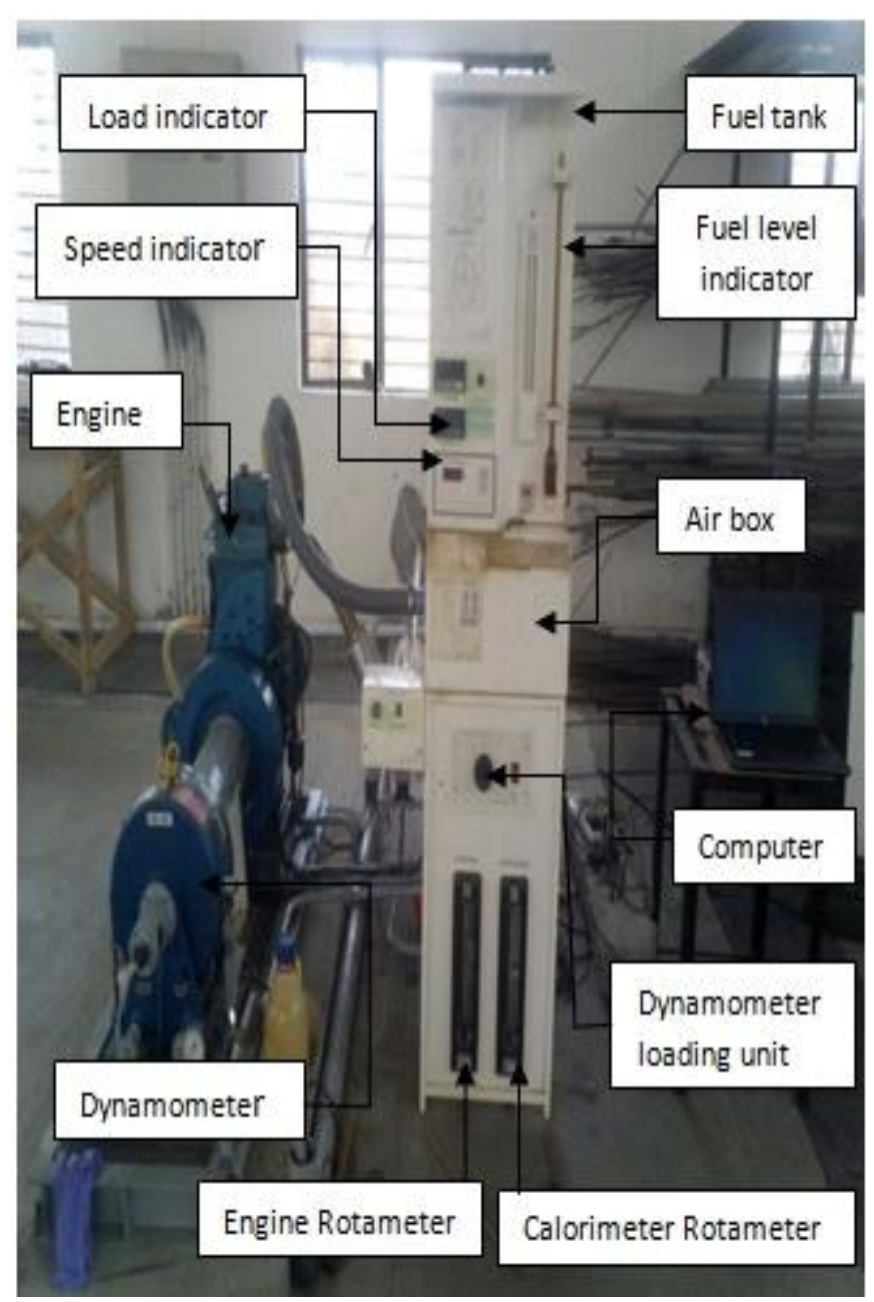

Fig -9: Experimental Setup. 
Table -3: Property of argemone oil, biodiesel and blends in comparison with diesel

\begin{tabular}{|c|c|c|c|c|c|c|c|c|}
\hline Test & Unit & Test method & Argemone oil & AB100 & AB 10 & AB 20 & AB 30 & Diesel \\
\hline $\begin{array}{l}\text { Density at } \\
40^{\circ} \mathrm{C}\end{array}$ & $\mathrm{g} / \mathrm{cm}^{3}$ & $\begin{array}{l}\text { ASTM } \\
\text { D1250 }\end{array}$ & 0.905 & 0.868 & 0.822 & 0.8267 & 0.832 & 0.821 \\
\hline $\begin{array}{l}\text { API } \\
\text { Density at } \\
15^{\circ} \mathrm{C}\end{array}$ & $\mathrm{g} / \mathrm{cm}^{3}$ & $\begin{array}{l}\text { ASTM } \\
\text { D1250 }\end{array}$ & 0.92182 & 0.886 & 0.8391 & 0.8449 & 0.850 & 0.808 \\
\hline $\begin{array}{l}\text { Specific } \\
\text { Gravity at } \\
40^{\circ} \mathrm{C}\end{array}$ & -------- & $\begin{array}{ll}\text { ASTM } & \text { D } \\
1250 & \end{array}$ & 0.9122 & 0.875 & 0.8272 & 0.8382 & 0.8388 & 0.814 \\
\hline $\begin{array}{l}\text { Kinematic } \\
\text { Viscosity } \\
\text { at } 40^{\circ} \mathrm{C}\end{array}$ & cst & $\begin{array}{l}\text { ASTM } \\
\text { D446-12 }\end{array}$ & 35 & 5.07 & 2.97 & 3.22 & 3.30 & 2.63 \\
\hline $\begin{array}{l}\text { Carbon } \\
\text { Residue }\end{array}$ & $\%$ wt & $\begin{array}{l}\text { ASTM } \\
\text { D4530 }\end{array}$ & 0.61 & 0.02 & 0.028 & 0.032 & 0.04 & 0.01 \\
\hline Flash Point & ${ }^{\circ} \mathrm{C}$ & $\begin{array}{l}\text { ASTM D92- } \\
\text { 12B }\end{array}$ & 220 & 130 & 75 & 83 & 95 & 65 \\
\hline $\begin{array}{l}\text { Molecular } \\
\text { Weight }\end{array}$ & $\mathrm{g} / \mathrm{mol}$ & & 730 & ----- & ----- & ----- & ---- & 230 \\
\hline $\begin{array}{l}\text { Moisture } \\
\text { Content }\end{array}$ & $\%$ wt & ASTM E-871 & 0.7 & 0.2 & 0.028 & 0.034 & 0.043 & 0.02 \\
\hline Acid Value & $\underset{/ g}{\operatorname{mgKOH}}$ & $\begin{array}{l}\text { ASTM } \quad \text { D } \\
974 N\end{array}$ & 4.7 & 0.34 & 0.015 & 0.21 & 0.35 & 0.01 \\
\hline FFA & $\%$ & & 2.35 & 0.25 & 0.059 & 0.105 & 0.175 & 0.05 \\
\hline $\begin{array}{l}\text { Calorific } \\
\text { Value }\end{array}$ & $\mathrm{MJ} / \mathrm{kg}$ & $\begin{array}{lr}\text { IS: } & 1359- \\
1959, & \text { BS } \\
1016 ; P a r t & \\
5.1967 & \text { IP } \\
1263 \mathrm{~T} & \end{array}$ & 36.72 & 39.41 & 42.3 & 41.36 & 40.56 & 43 \\
\hline Fire point & ${ }^{\circ} \mathrm{C}$ & $\begin{array}{l}\text { ASTM D92- } \\
\text { 12B }\end{array}$ & 230 & 138 & 78 & 87 & 105 & 68 \\
\hline
\end{tabular}

\section{RESULT AND DISCUSSION}

\subsection{Optimization of Biodiesel with Different}

\section{Reaction Parameters}

In this optimization of biodiesel with various reaction parameters was discussed.

\subsubsection{Effect of Reaction Temperature on Biodiesel}

\section{Yield and Kinematic Viscosity}

The kinematic viscosity and biodiesel yield changes with change in reaction temperature. Reaction temperature varied between $55-85^{\circ} \mathrm{C}$ for different experiments. The biodiesel yield decreases with the increase in reaction temperature. The biodiesel yield was highest and kinematic viscosity was smallest under the optimum reaction temperature at $75^{\circ} \mathrm{C}$.
The effect of reaction temperature on the biodiesel yield (\%) and kinematic viscosity was shown by figure $(10 \& 11)$. 


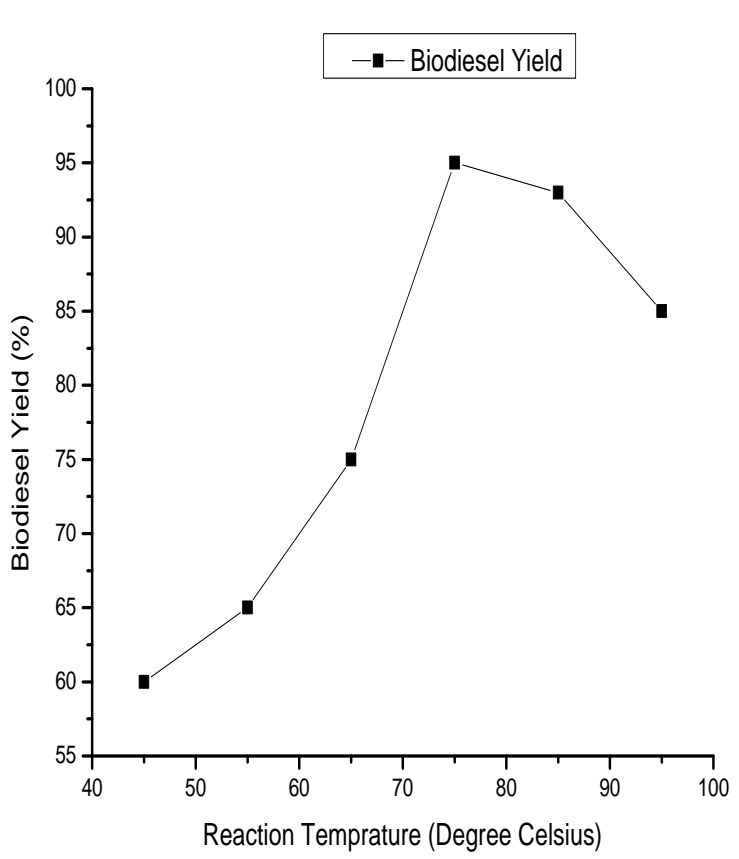

Fig -10: Effect of reaction temperature Vs Biodiesel Yield.

\subsubsection{Effect of Molar Ratio on Biodiesel Yield and}

\section{Kinematic Viscosity}

Different type of molar ratio 1:3, 1:6, 1:9 (oil to methanol) were used during the different experiment conducted. The optimum ratio of maximum conversion rate was 1:6 (oil to methanol).

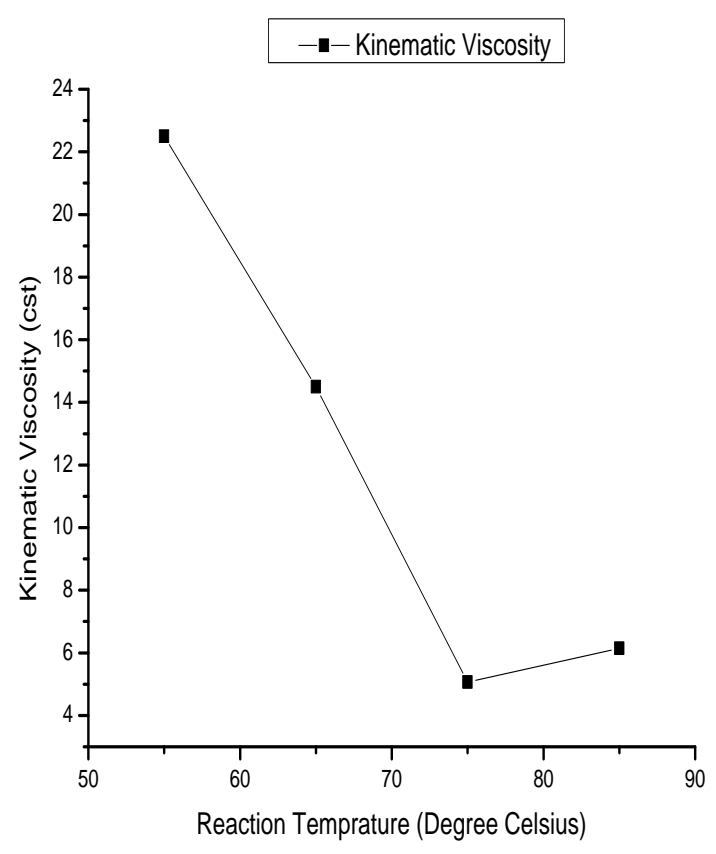

Fig -11: Effect of Reaction Temperature Vs Kinematic Viscosity

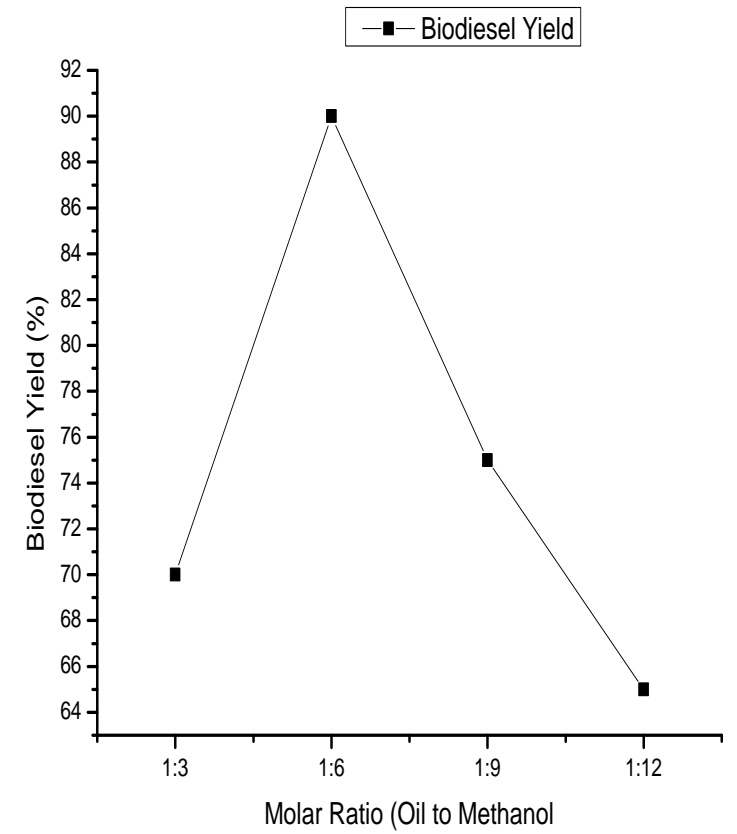

Fig -12: Effect of Molar Ratio Vs Biodiesel Yield.

Higher molar was used during experiment, the density difference between upper layer (biodiesel) and lower layer (glycerol) becomes much less. The separation becomes very difficult and conversion rate decrease. High amount glycerol content in the biodiesel leads to higher kinematic viscosity. The optimum molar ratio was 1:6 (oil to methanol) gives $90 \%$ yield of biodiesel and reduced kinematic viscosity. The effect of molar ratio on biodiesel yield (\%) and kinematic viscosity were shown in figure (12 \& 13).

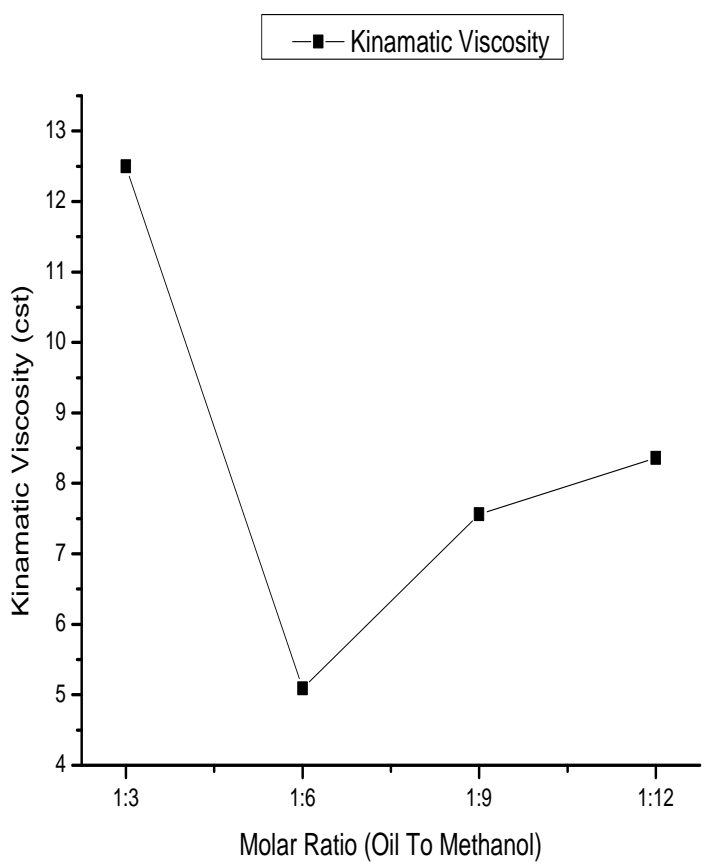

Fig -13: Effect of Molar Ratio Vs Kinematic Viscosity 


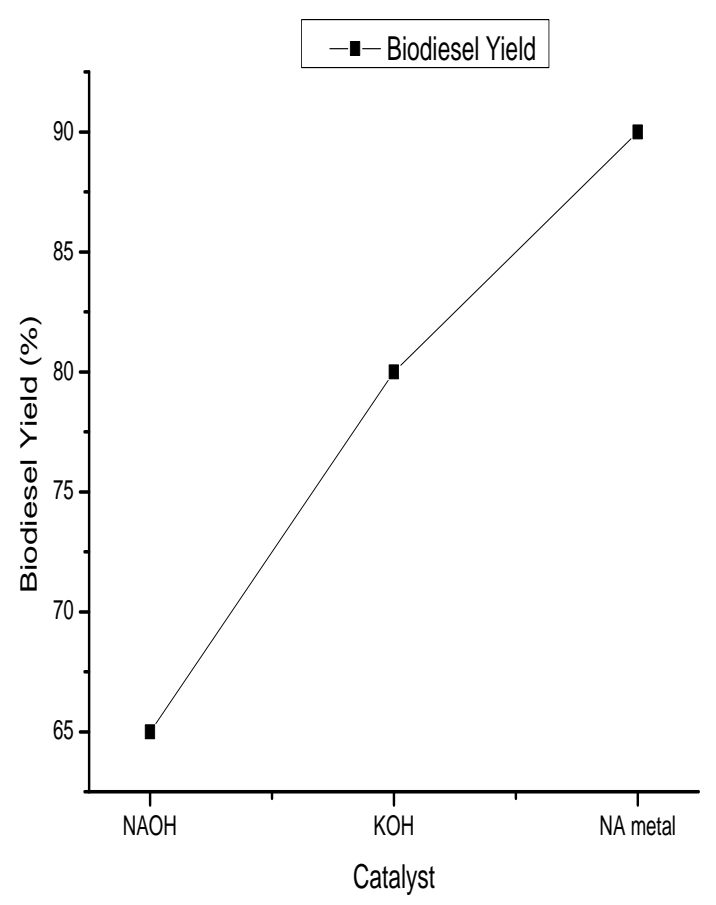

Fig -14: Effect of Catalyst Vs Biodiesel Yield.

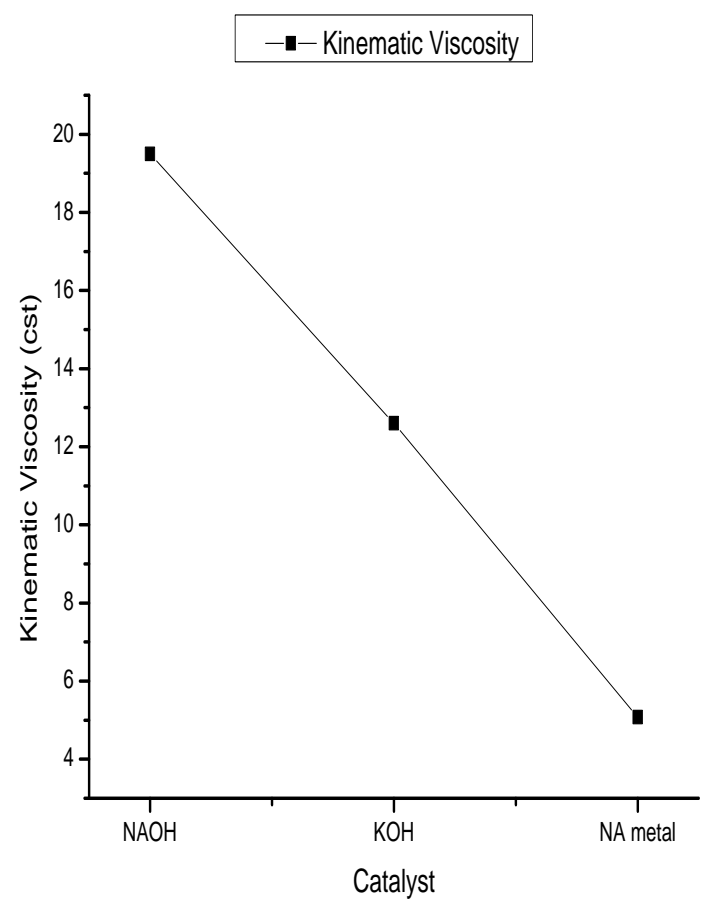

Fig -15: Effect of Catalyst Vs Kinematic Viscosity

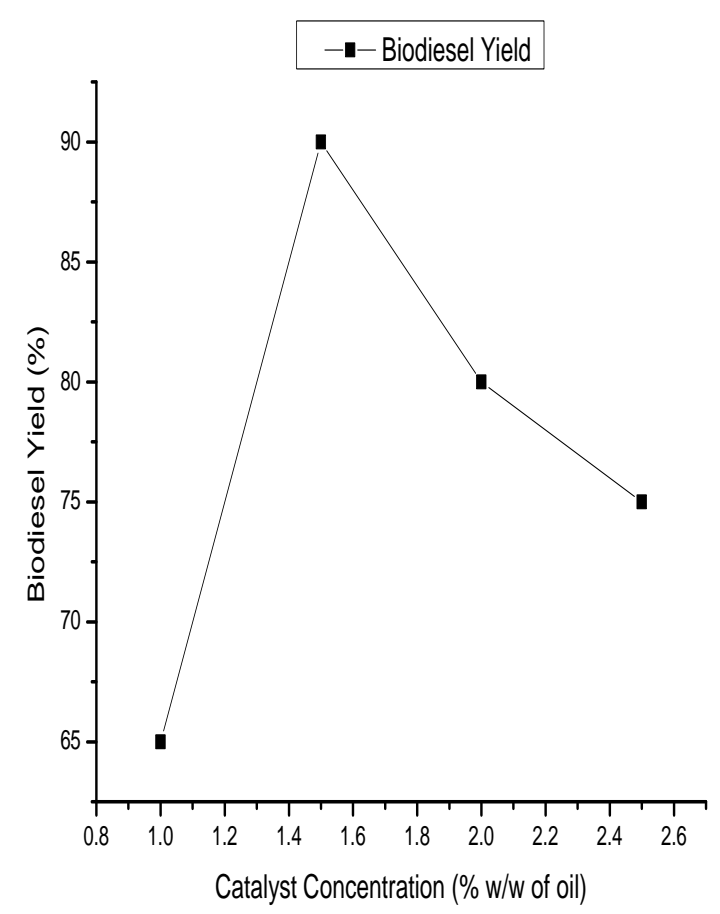

Fig -16: Effect of Catalyst Concentration Vs Biodiesel Yield

\subsubsection{Effect of Catalyst Concentration on Biodiesel}

\section{Yield and Kinematic Viscosity}

During the production of biodiesel three types of catalyst $\mathrm{NAOH}, \mathrm{KOH}, \mathrm{NA}$ metal and catalyst concentration $1.5,2$, $2.5 \%$ (w/w of oil) were used. Maximum biodiesel yield is obtained for the catalyst NA metal with concentration $1.5 \%$ (w/w of oil) react with alkali catalyst) that decreases biodiesel yield and kinematic viscosity increased [10]. The effect of If high amount of catalyst concentration was used, it will produce more soap formation (extra triglyceride to catalyst and catalyst concentration on biodiesel yield (\%) and kinematic viscosity were shown in figure $(14,15,16$ $\& 17)$. 


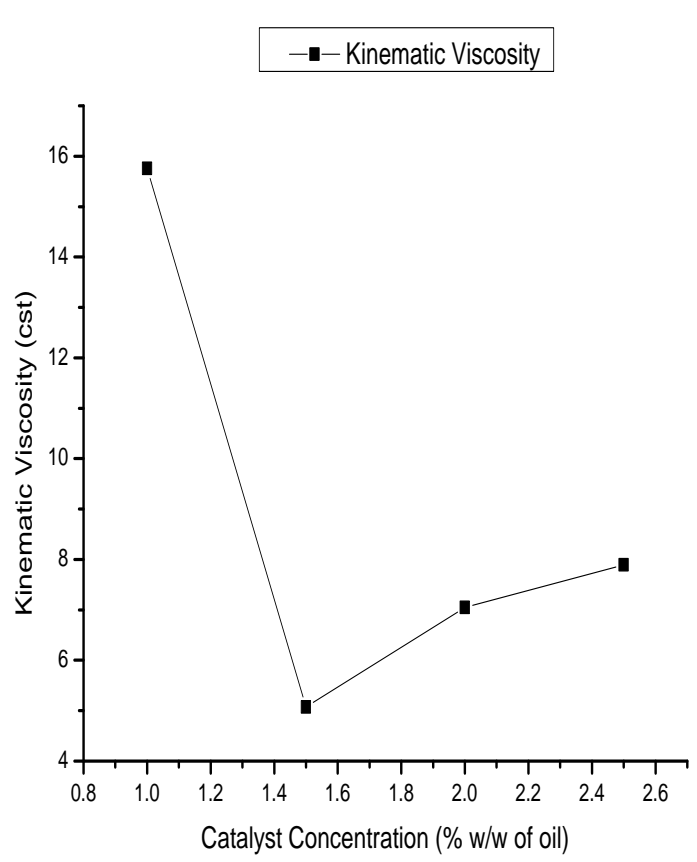

Fig -17: Effect of Catalyst Concentration Vs Kinematic Viscosity.

\subsection{Engine Performance}

The single cylinder CI engine performance parameters of argemone biodiesel was evaluated in terms of Brake power, brake thermal efficiency and brake specific fuel consumption at different loading (no load, 20\%, 40\%, 60\%, $80 \%, 100 \%$ ) conditions.

\subsubsection{Brake Power}

The brake power was increased with increase in load. The brake power was maximum value $(4.27 \mathrm{KW})$ for $\mathrm{AB} 20$ at full load condition. The brake power was maximum due to better combustion and high amount of heat content in the biodiesel.

\subsubsection{Brake Thermal Efficiency}

The brake thermal efficiency was increases with increase in load on engine. The brake thermal efficiency was maximum for $\mathrm{AB} 20(31.95 \%)$ at full load conditions. The brake thermal efficiency for AB20 was maximum than that of diesel fuel due -to high amount of oxygen content are present in the argemone biodiesel fuel. This value indicates that decrease in heat loss and increase power output with maximum load condition. For AB30 BTE was decreased than that of diesel due to lower calorific value of fuel.

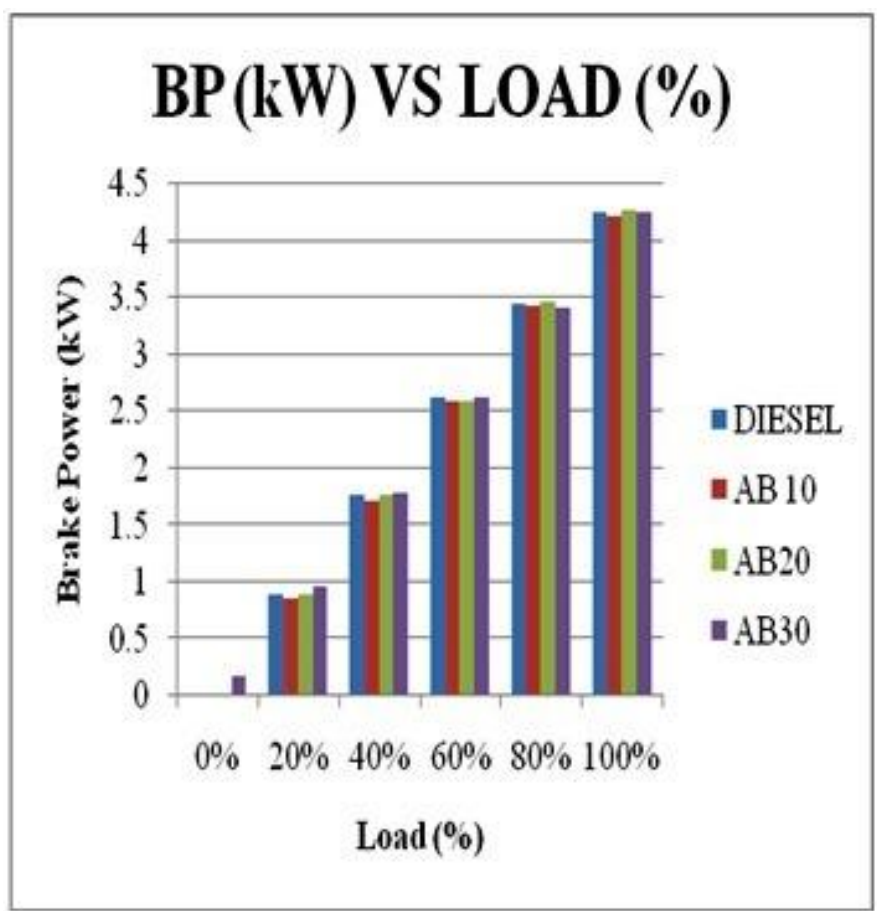

Fig -18: Variation of BP (kW) vs Load (\%).

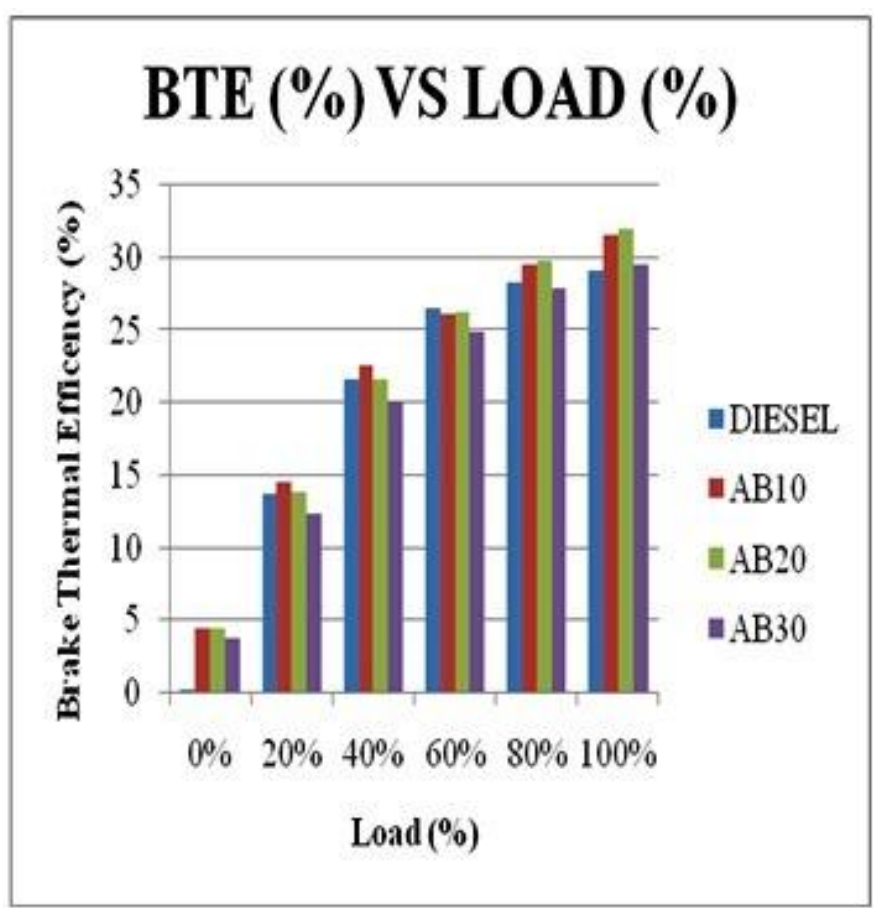

Fig -19: Variation of BTE (\%) vs Load (\%)

\subsubsection{Specific Fuel Consumption}

The specific fuel consumption was decreased for different load conditions. The specific fuel consumption value was slightly higher than that of diesel fuel for AB10, AB30 but AB20 value was lower than that of diesel fuel at full load condition. Specific fuel consumption value was lower because of high amount of oxygen contant present in the biodiesel they lead to proper combustion and decrease the specific fuel consumption value. 


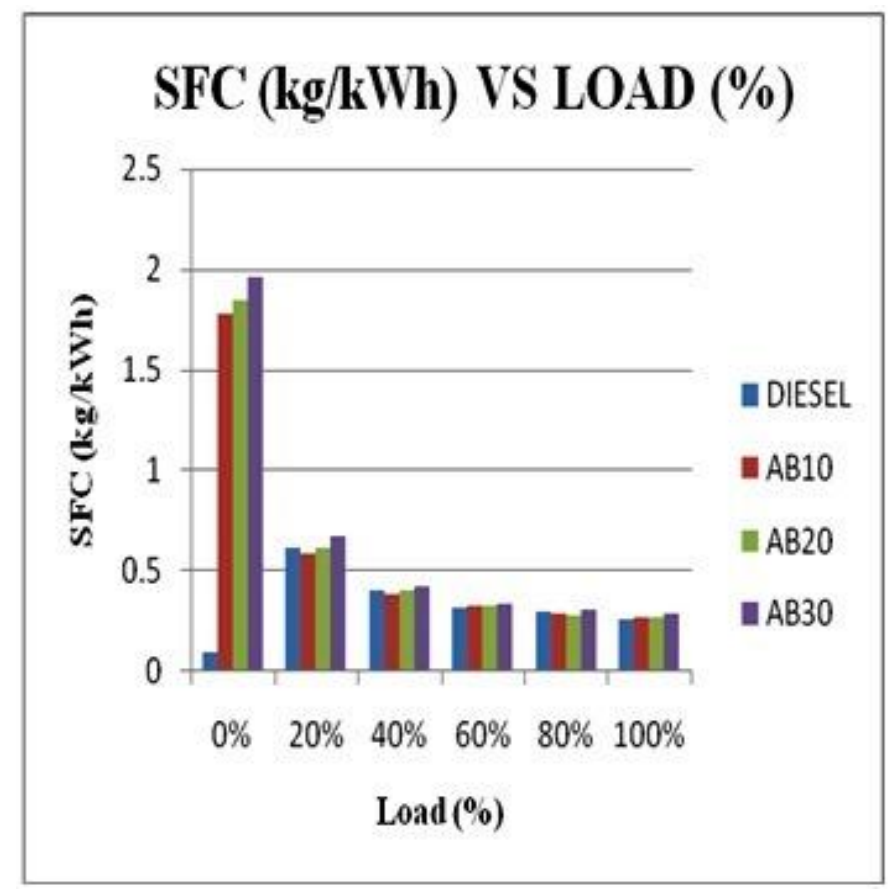

Fig -20: Variation of SFC (kg/kWh) vs Load (\%).

\section{CONCLUSION}

In this study the optimum condition for production of biodiesel from argemone oil and performance analysis on single cylinder CI engine fuelled with argemone biodiesel blends with diesel, the following conclusion have been made in this work

1. The production of biodiesel was highest by single step transesterification of argemone oil with methanol in the presence sodium metal as a catalyst. The biodiesel yield of maximum $90 \%$ and kinematic viscosity of minimum $5.07 \mathrm{cst}$ were obtained molar ratio (1:6 oil to methanol) at $75^{\circ} \mathrm{C}$.

2. The optimum condition for production of biodiesel were 1:6 oil to methanol ratio, catalyst sodium metal, catalyst concentration $1.5 \% \mathrm{w} / \mathrm{w}$ of oil, reaction time 2 hour, reaction temperature $75^{\circ} \mathrm{C}$, and stirring speed $650 \mathrm{rpm}$.

3. The brake thermal efficiency and brake power of was maximum for AB20 at full load conditions. Due to high amount of oxygen content are present in the fuel, they lead to proper combustion and better atomization of fuel.

4. The specific fuel consumption was decreased for AB20 at full load conditions even that of diesel fuel. This is due to excess of oxygen content are present in biodiesel and lower viscosity and density of fuel.

5. The friction power was decreased at no load condition for all blends and increased by full load condition. the frication power was maximum for AB30 at full load conditions

Therefore it can be concluded that the argemone biodiesel blend AB20 (biodiesel $20 \%+80 \%$ diesel by volume) has improved fuel properties for diesel engine and improved performance.

\section{REFERENCES}

[1] R K Singh, Saswat Rath, "Performance Analysis of Blends of Karanja methyl ester in a Compression Ignition Engine" International Conference on Biomedical Engineering and Technology IPCBEE Vol. 11 (2011), Pages 187-192

[2] Oguz Yunus Saribiyik, Mustafa Ozcanli, Hasan Serin, Selahatattin Serin, Kadir Aydin, "Biodiesel production from Ricin Communis Oil and its Blends with Soybean Biodiesel" Strojiniski vestnik- journal of Mechanical Engineering 56(2010)12, Pages 811816, UDC 662-756.3

[3] Vivak, A K Gupta, "Biodiesel production from karanja oil" Journal of Scientific and Industrial Research Vol. 63, January 2004, pp 39-47

[4] Hulya Karabas, "Investigation of Biodiesel fuel from Canola oil using various Reaction Parameters" International Journal of Automotrive Engineering and Technologies, Vol. 2, Issue 3, pp. 85-91, 2013

[5] Ahamed Hasan AI-Baizy, "Phytochemical Screening and in vitro Antioxidant and Thermbolytic Activities of Argemone mexicana extracts" July 2012, ID: 2010-3-79-013

[6] P. Pramanik, P.Das, P.J. Kim“"Preparation of biofuels from argemone seed oil by alternative cost effective technique" Fuel 91 (2012), Pages 81-86

[7] Premkumar, M P sharma, Gaurav Dwivendi, "Impact of Biodiesel on Combustion, Performance and Exhaust Emission of Diesel Engine" Journal of Integerated Science Technology, Vol 2, No 2 (2014), Pages 57-63

[8] A. K Azad, S.M. Ameer Uddin, M.M. Alam, "Mustard oil, an alternative Fuel: An experimental investigation of biodiesel properties with and without trans-esterification reaction" Global Advanced Research Journal of Engineering, Technology and Innovation, Vol.1 (3) June, 2012, Pages 075-084,

[9] Ashish Sithta, Ashwani Kumar, S.K. Mahla, "Utilization of Argemone Oil Biodiesel in Commercial Di-Ci Engine" International journal on Emerging Technologies 3(2): (2012), Pages 19-23

[10] .Alhassan Y., Kumar N, Bugaje I.M., Mishra C. "Optimization of Gossypium arboreum seed oil biodiesel production by central composite rotatable model of response surface methodology and evaluation of its fuel properties" Journl of petroleum Technology and Alternative Fuels, Vol. 5(1), February 2014, Pages 1-12.

[11] Sandeep kumar duran, Manider singh, Hardeep Singh, "Performance and combustion characteristics of singleCylinder diesel engine fuelled with blends of karanjaBiodiesel and diesel" International Journal of Mechanical Engineering and Technology Volume 5, Issue 7, July (2014), pp. 160-170,

[12] Sandeep Kumar Duran, Maninder Singh, Hardeep Singh, "Karanja and Rapeseed Biodiesel: An Experimental Investigation of Performance and Combustion Measurement for Diesel Engine" International Journal of Scientific and engineering Research, Volume 6, Issue 1, January 2015, ISSN 2229-5518 


\section{BIOGRAPHIES}

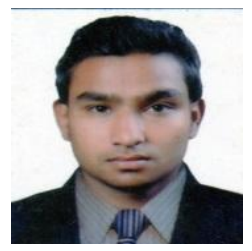

Mr. Parmjit, M.Tech research scholar (thermal engineering) from Lovely Professional University and his area of interest in research area is thermal consideration in biofuels.

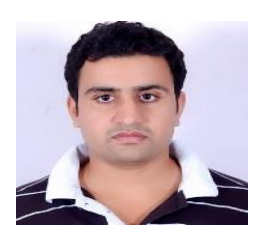

Sandeep Kumar Duran is working an Assistant Professor in Mechanical Department (Thermal Engineering) at Lovely Professional University, Jalandhar. He is pursuing his $\mathrm{PhD}$ (Bio Fuel) from NIT Jalandhar. He has 3 years' experience in research and his area of interest includes heat transfer and Bio Fuel.

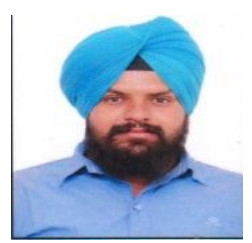

Mr. Amanpreet Singh M.Tech research scholar (thermal engineering) from Lovely Professional University and his area of interest in research area is thermal consideration in biofuels. 